\title{
Children as Consumers of Historical Culture in Finland
}

\author{
Rantala, Jukka
}

2011

Rantala , J 2011, ' Children as Consumers of Historical Culture in Finland ', Journal of

Curriculum Studies, vol. 43 , no. 4 , pp. 493-506 . https://doi.org/10.1080/00220272.2011.584563

http://hdl.handle.net/10138/37305

https://doi.org/10.1080/00220272.2011.584563

acceptedVersion

Downloaded from Helda, University of Helsinki institutional repository.

This is an electronic reprint of the original article.

This reprint may differ from the original in pagination and typographic detail.

Please cite the original version. 
This is an Author's Accepted Manuscript of an article published in Journal of Curriculum Studies, 43:4, 493-506 (27 Jun 2011) [copyright Taylor \& Francis], available online at: http://dx.doi.org/10.1080/00220272.2011.584563

Jukka Rantala

\section{Children as Consumers of Historical Culture in Finland}

The article examines the reception of history by 7-10-year-old children in Finland and the role of historical culture in the formation of children's conceptions of the past. It scrutinises how history is used to build individual and collective identities and bring significance to the past in children's everyday lives. Interviews with 174 pupils in a primary school in Helsinki constitute the basis of the research. The study reveals that children's perceptions of the past are compounded above all by active reminiscence by their parents and grandparents, who in particular are retelling stories of the wars between Finland and the Soviet Union (1939-1944). Through these stories the older generations are trying to connect their families to the national Great Tradition. The study also claims that women are more active mediators of the past than men.

Keyword: Historical consciousness, historical culture, history instruction, cultural awareness

\section{Introduction}

In recent years historical consciousness has been a central theme among historians and history educators. Researchers have been interested in a number of issues, including how people use the past to explain the present, how people orientate themselves towards the future with the help of perceptions gained from the past, how history is used to form collective and individual identities, and the role of history in people's lives. Historical consciousness is currently being examined in Finland by a survey of 1200 adults, in a study that will involve interviews focusing, among other things, on young children's conceptions of the past (Rantala 2009).

Where do people acquire their conceptions? At school students learn the official image of history. However, the role of instruction has decreased in parallel with the emergence of informal historical culture. According to researchers, movies, novels, computer games and role-playing will leave a more permanent mark on today's people than formal education. (E.g. Ahonen 1997, A261; Aronsson 2000; Ashton and Hamilton 2003, 7, 12; Rosenzweig and Thelen 1998, 12.) In addition, the reminiscences of parents and other relatives will also have a strong influence.

The historical consciousness of adults and upper secondary school youth has been studied quite extensively (e.g. Rosenzweig and Thelen 1998, Ashton and Hamilton 2003, Angvik and Borries 1997, Ahonen 1998). Children's perceptions of the past and the significance of historical culture in forming them, however, have never been studied. The purpose of this study is thus to determine how the historical consciousness of 7-10-year-old Finnish children is created. 


\section{The importance of historical culture in forming historical consciousness}

The current study focuses on children's conceptions of the past and how they are formed. A conception of the past comprises ideas and beliefs and it is tied to time and culture. Each person has some conception of the past and it has been largely formed on the basis of historical culture.

Historical culture contains all cultural areas where one meets history. Movies, fairy tales, monuments, museums, and historical novels, among other things, belong to historical culture as well as new intermediary channels, such as computer games. Historical culture appears to be thriving all around us, with historical literature as well as television and movie dramas being quite popular. History has been restored in a growing variety of exhibitions and public events that are connected with different national celebrations. History is also presenting itself in our lives more imperceptibly: consumer goods and clothing feature nostalgia; music is recycled with new arrangements; the photography business invites us to order albums of digitalised photos of our past. Even the youngest children can orientate themselves to history by playing with historical Lego characters. Further, history researchers influence people through their work and teachers by more formal instruction. And more and more people are realising the significance of the past with the help of new IT media.

The concept of historical culture is rather clearly definable and there are no major interpretative disagreements about it among researchers. However, some researchers divide historical culture in slightly different ways. Swedish researcher Klas-Göran Karlsson defines historical culture as the whole comprising the historical communications surrounding people (Karlsson 2004: 34). In Finland, Jorma Kalela (2000: 38-39) has divided historical culture into representations of 'official' history and 'unofficial' vernacular history. In Kalela's division, the public representations of history include academic research and school teaching, and, for example, films and TV series set in bygone eras. Vernacular history is present in the stories about the past related among a family or a work community. The Joint European 'Youth and History' study revealed that the Finnish view of history is founded strongly on vernacular history - young Finns were more eager than young people in other countries to listen to adults and to also trust them (Ahonen 1998: 19).

An individual's perception of history is essentially linked to his/her historical consciousness, an understanding of how he/she relates to the present time and how he/she will orientate him/herself towards the future. Nowadays researchers see the past-present-future relation as bidirectional: the past affects our expectations of the future, and equally our future expectation will affect the way we view the past (e.g. Seixas 2004, Jensen 1998: 68). People's historical consciousness is often constructed in a narrative form (Rüsen 2004: 63-82). In their family narrations people have supporting structures that are often grounded in the Great Narratives, such as the story of the nation-state. Many Finns have integrated their family narratives with the struggle for survival against the Soviet Union in 1939-1944. Thus Finns have derived optimism with respect to their current difficulties - economic, for example - from their knowledge of the past. On the other hand, Finns can separate their personal coping from the development of Finland or the European Union. This has been 
reflected among young Finns by, among other things, a strong faith in their personal survival when, at the same time, they have had quite pessimistic expectations concerning the general development of their own continent (Ahonen 1998, Rubin 1998: 118, 150, 167).

Roy Rosenzweig and David Thelen's study indicates that people in the United States identify themselves more with their family history than with the national narrative (Rosenzweig and Thelen 1998: 9, 31, 63, 109-114, 177, 191). Finnish identity, on the other hand, is very much anchored to the national story (Ahonen 1998; 129-132, Ahonen 1999: 33-35, van den Berg 2007: 258-261). Initially the formation of a strong national identity was a consequence of formal education. However, the entertainment industry has nowadays an even stronger influence on youth than school education. Young Finns become attached to the national narrative by watching Finnish war movies, especially 'The Unknown Soldier', perennially the most popular Finnish movie (Ahonen 1998: 169-170). ${ }^{1}$ Often there is also a common vision of threats connected with the national narrative. Historical culture helps individuals and factions to cultivate their historical identities, but not always in terms of benevolent means and outcomes. Some use historical culture to create and maintain negative images of ethnic groups or nationalities Finnish historical identity has largely been based on the threat posed by Russia, which is still explicit in Finnish history textbooks today (Harle and Moisio 2000: 15, 55-56, Suutarinen 2000, Länsiluoto 2008: 125 133). Even though the nationalistic Grand Narrative of Finnish history has a strong influence on young children's perceptions of history, its importance seems to be weakening as Finnish society changes due to multiculturalism and globalisation. More and more, young people are identifying themselves with attributes other than national ones, something which seems to be occurring also among Finnish adults (Knuuttila 2009: 77). The nationalistic Grand Narrative, however, is not about to vanish; rather it will include other narratives as well (Knuuttila 2009: 89-90). ${ }^{2}$

Presumably the historical consciousness of children and adults differs. Knowledge relating to the past is the building material of historical consciousness, and in general adults have acquired more historical information than children. Also their attitude handling information differs from young people's. Mature individuals have developed a critical attitude towards information into through their formal education and personal experiences. Children, on the other hand, have an ambivalent attitude towards historical information: for them it is often either fact or fiction. Young children also see history as a linear story of progress. (Lee and Ashby 2001: 26.)

A limited knowledge of history combined with a belief in the superiority of the present would seem to mean that young children should strongly believe in progress and have positive expectations of the future. Yet some scholars have argued that it is fruitless to investigate the historical consciousness of children because they do not think abstractly. Hence they argue that research should concentrate on children's

\footnotetext{
${ }^{1}$ Finnish television's channel 2 (YLE2) has shown 'The Unknown Soldier' every Finnish Independence Day since the beginning of this century. http://en.wikipedia.org/wiki/The_Unknown_Soldier_(1955_film), accessed January 29, 2011. 2 There are signs of similar developments elsewhere in the world. For example, Christian Laville (2004: 165-176) argues that nowadays history education that strengthens nationalism is unthinkable because forms of remembrance and identification are more diverse than in the past.
} 
historical culture rather than historical consciousness (e.g. Haue 2008: 53-56, see also VanSledright 2002: 7-9 and Cooper 1994). It is true that young children do not have a long historical perspective, and neither can they feel nostalgia similar to adults. It is also imaginable that they cannot be interested in family history in the same way as their parents because their conception of time is insufficient. However, no-one has studied 7-10-year-old children's perspectives on the future. Moreover, only a small amount of research has been done on the historical understanding of this age group. Therefore there is no certainty that young children have as limited an understanding of the past as has been assumed.

Previous studies suggest that before the commencement of history education at school young people have already formed such strong views of history that it is difficult to influence their opinions through teaching. Strong standpoints have been compounded especially by themes related to linguistic and cultural identities (Létourneau 2006: 78-84; Létourneau and Moisan 2004: 118-122, cf. Cooper 2000: 159-160). For pedagogues planning history education it is thus vital to be aware of the conceptions children have before they begin history instruction.

The aim of the current study is to determine the significance of 'official' and 'unofficial' (vernacular) historical culture in the formation of children's conceptions of the past. On the one hand, the aim is to find out how films, TV programmes and literature related to the past and, on the other hand, reminiscences of parents and grandparents are present in the everyday life of children. The research will give pointers about children's historical consciousness - about how children explain the present with the help of information derived from historical culture and how they orientate towards the future on the basis of an understanding thus formed.

\section{The influence of television and literature on young children's perceptions of the past}

The purpose of this study is to determine, from whom or where young children acquire their knowledge of the past and the nature of their historical understanding. Previous studies in Finland have suggested that the intergenerational transmission of historical knowledge has become weaker and that the entertainment business will have a growing effect on the forming of adolescents' conceptions of the past (Ahonen 1998). A special aim of the study is therefore to discern what kind of effect the family has on young children's perceptions of the past.

The research was based on a qualitative study conducted by the author. Altogether 174 interviewees were selected from the Arabia Comprehensive School in Helsinki. The author and student teachers from the Department of Teacher Education of the University of Helsinki carried out the interviews. Arabia Comprehensive School is a training school associated with the University of Helsinki, and pupils are accustomed to student teachers. Even though the school cooperates with the University of Helsinki it has no special status among the city's schools - it is a typical Finnish comprehensive school.

The interviews were conducted in 2008 and 2009. The interview questions were based on the questionnaire from the Historical Consciousness in Finland study (Historical 
Consciousness in Finland). The number of questions was decreased due to the interviewees being so young, and the questions were made more suitable for young children. Questions on the use of historical culture focused on children's television watching and reading habits. Family remembrance practices were explored by asking about acts of remembering, instances of looking at photos, and mementos at home. The interviews lasted 40 to 60 minutes each.

Table 1. The interviewees (n 174)

\begin{tabular}{|c|c|c|c|c|}
\hline Grade & Pupils' age & Girls & Boys & Total \\
\hline 1 & 7 & 39 & 38 & 77 \\
\hline 2 & 8 & 35 & 30 & 65 \\
\hline 3 & 9 & 7 & 11 & 18 \\
\hline 4 & 10 & 8 & 6 & 14 \\
\hline Total & & 89 & 85 & 174 \\
\hline
\end{tabular}

The study's purpose was to examine where children acquire their knowledge and beliefs about the past. In Finland 7-10-year-olds have not yet begun to study history at school. Therefore one can assume that the official historical culture has had little influence on young children's perceptions of the past. Family remembrance practices, in contrast, ought to have a great effect as children of that age are closely tied to the home, and 7-10-year-old Finns consume less mass entertainment than they will later in life.

Siep Stuurman and Maria Grever emphasised the massive changes that have occurred in the field of historical culture. The mediating channels in historical culture have greatly diversified within two generations. Some mediators of history have basically remained the same for decades, such as family and relatives, education, literature, movies and museums. Still, some changes have occurred among these. For example, the significance of tradition and education has decreased whereas that of movies has increased. The substantial change in the forming of young people's reception of the past has occurred with the emergence of the new mediator channels of history. Especially among young people, the Internet and computer games have outpaced the old means of mediation. According to Stuurman and Grever, historical culture has become richer and more complex, but also more fragmented and labyrinthine (Stuurman and Grever 2007: 10-11).

On the Internet young children rarely encounter issues related to the past. In Finland the most popular Internet utilities among young people are the search engine Google, the instant messaging application MSN Messenger and the YouTube application (Kangas et al. 2008). Similar results have turned up globally. According to these surveys, children are using the Internet mostly for music, movies and television (Kids' Top 100 Searches of 2009). In this study, the Internet was excluded because seemingly 7-10-year-old children do not use it for seeking knowledge of the past. In addition, computer games were also not discussed in the interviews because in 
computer games popular among young Finns there is no strong connection to the past. $^{3}$

Young children become acquainted with the past especially through television.

Almost all the interviewees were able to mention by name television programmes or films related to history which they had seen within the previous 12 months. The past was presented mostly through movies (78 mentions), historical fiction programmes (62 mentions) and documentaries (53 mentions).

The interviewees named 84 different historical programme titles. Nevertheless, the children had few shared favourites. Only the French animation, Once upon a time (Il était une fois...l'Homme, 1978) was more common: every sixth interviewee reported watching the programme. The popularity of the series is based on its style of recounting history in an understandable way for young children. In the programme, the same characters roam through history, from the Stone Age to the present day. The series contains dozens of episodes and has been presented several times in Finland. It is also very likely that the interviewees' parents watched the series when they were young.

Many interviewees mentioned having watched documentaries or films related to dinosaurs within the past 12 months. Of these, 19 reported having watched documentary programmes on the subject. In addition, 17 interviewees had seen Ice Age animations, ${ }^{4}$ and two the movie Jurassic Park. Dinosaurs thus seemed to be of particular interest. Non-fiction books on the same theme also appeared to be popular, and many interviewees mentioned 'the time of dinosaurs' when asked to name their favourite period in history. However, the above-mentioned viewing figures illustrate that the viewing culture of children has become fragmented. The interviewees mentioned having watched a total of 37 movies within the past 12 months, but no movie was named more than twice except Ice Age.

In contrast to television programmes and films, the children's reading material appeared as more uniform. The interviewees highlighted 43 different literature titles related to the past that they had read within the previous 12 months. Of the 174 interviewees, 119 reported having read Mauri Kunnas's children's books where fiction and non-fiction concerning the past are combined. ${ }^{5}$ In particular, the interviewees mentioned the Doghill series, situated in a Finnish peasant community in the $19^{\text {th }}$ century. In turn, 41 children had read The Kalevala, the national epic of Finland. The Kalevala had been read mostly at kindergarten and primary school. Of comics or graphic novels the most popular was Walt Disneys' Donald Duck, read by 32 interviewees, while eight had read René Goscinny and Albert Underzo's The Adventures of Asterix (Astérix le Gaulois).

\footnotetext{
${ }^{3}$ During the recent years various types of sport and music games have dominated the computer game markets among less than 12-year-old children. See Kangas et al. 2008: 10.

${ }^{4}$ The Ice Age movie series came out between 2002 and 2009: Ice Age (2002), Ice Age 2 - The Meltdown (2005), and Ice Age 3 - Dawn of the Dinosaurs (2009).

${ }^{5}$ Mauri Kunnas's books are based on animal characters, as with Richard Scarry's work. Kunnas is the most successful author of children's books in Finland. He has published books for example on the Vikings, the Wild West and the Knights of King Arthur. http://www.maurikunnas.net/mauri_kunnas/teokset/en_GB/works/
} 
It is known that J. K. Rowling's Harry Potter and C. S. Lewis's Chronicles of Narnia are the most popular fictional novels among young Finns. In this study, however, only five children reported having read them. Children of this age do not yet read such novels by themselves. All the same, it is worth noting that the interviewees believed the novels to be based on history.

Dinosaur books were the most popular non-fiction: 15 interviewees had read such books. The spectrum of non-fiction books relating to the past was broad. The interviewees mentioned books on fossils, the history of football, the birth of the Universe, etc. Some children mentioned the Bible as a book relating to the past.

In summary, no common television programmes or films that appear to have formed the children's perceptions of the past. Children 7 to 10 years of age watch mainly children's programmes, and in Finland they watch less television as a whole than teenagers or young adults (Noppari et al. 2008: 108-110, Koivusalo-Kuusivaara 2007: 45-46). Children at that age will more willingly concentrate on literature. They read on their own and their parents read to them. The children are getting their knowledge of the past through children's books, and mainly by the author Mauri Kunnas. Nevertheless, the above-mentioned mediums still do not have as big an influence on children's perceptions of the past as family remembrance, the subject of the next section.

\section{The significance of family remembrance in the formation of young children's conceptions of the past}

Family is an important factor in the formation of a child's perceptions of the past. In Finland, 7-10-year-olds are still closely tied to the world of home and the effects of, for example, youth culture are not as evident in them as they are in older children. They spend their leisure time at home, and especially girls spend time above all with their parents (Helve 1987, 1993, 2009). Likewise, 7-10-year-olds discuss the past mostly with their parents; for example, while watching television or visiting a museum. Children create a narrative in which they will locate their family in the larger social and historical context. Family traditions, photographs and mementos assist this process. With the aid of photographs, families recollect public occasions such as national commemoration days, as well as milestones like birthdays and graduations. Photo albums have occupied a prominent place in the bookshelves of families for generations.

In the present study, photographs appeared to be the key items that build children's perceptions of the past. All interviewees except four reported looking at photos with their family within the last 12 months. Most had looked at photos with their mother or with both parents. Grandparents and siblings were frequently involved as well. Most often children named their own infant photos and their parents' and grandparents' wedding and passport photos as pictures related to the past. Graduation photographs were also often mentioned. Through pictures, members of the older generation have been telling their own history to their descendants. In this way, photos function as enablers of intergenerational recollection. 
Ninety per cent of the interviewees mentioned the mementos they have at home. The spectrum of mementos was broad: the 174 interviewees talked about 128 different artefacts, for example furniture, tableware, toys, souvenirs, parents' and grandparents' personal belongings and home-made objects, and various kinds of prizes and valuables.

Arabia Comprehensive School is located centrally in Helsinki and the majority of the interviewees' parents were born in the city. However, a number of children noted cherishing agrarian relics - milking stools, spinning wheels and other farm items - in their homes, often inherited from their grandparents. Children also mentioned having such mementos as 'a wooden chair from the time of the war' and 'grandpa's clock'. The children's parents were also presenting the legacy of their own parents by displaying things like their old flatware, cups and coffee pots.

The interviewees were not as intimate with the agrarian relics as their parents' mementos, which they could list in the dozens. The mothers had stored their own dolls, dollhouses, rocking horses and stuffed animals, and fathers had preserved their slot cars, Dinky toys, model trains and Lego bricks, to mention only a few. Almost without exception, the mementos mentioned by the interviewees were toys that had been popular in the first half of the $20^{\text {th }}$ century, namely dolls or mechanical items. Only one interviewee named a Nintendo Game (from the beginning of the 1980s) as a memento from the time of his father's childhood.

Souvenirs as mementos were for the interviewees surprisingly few. Only a small numbers of children mentioned them, whereas the personal belongings and homemade objects of parents and grandparents were mentioned very often. The interviewees connected different kinds of family anecdotes to these home-made articles. Through them, the children had achieved an understanding that in the past people made toys and utensils themselves. Plenty of sentimental value has been connected to such objects, and even the children seemed to have felt the same way.

With the aid of these mementos, the interviewees had acquired a perception of paucity with respect to the past. 'When you didn't have money you had to make toys by yourself', as one interviewee expressed it. Mementos from the time of the interviewees' grandparents' youth were rare, which gave them an almost sacred aura in the children's eyes. Mementos concerning their parents, however, carried a very sentimental meaning. Even very ordinary objects, such as fathers' old flash-lamps and mothers' old mugs, were considered as mementos by the interviewees, particularly if their parents had associated them with anecdotes from the past. It can be concluded from the interviews that the interviewees' parents were longing for their own history. Parents' nostalgia about their own childhood is evident in that the interviewees could list many of their parents' toys and tell stories related to them. From this it can be seen that parents like to reminisce about their childhood with their offspring. Consequently they were telling stories of their own past to their children partly through different kinds of artefacts.

Even though the interviewees were without long personal perspectives of the past, many had mementos from their earlier childhoods. Some of these artefacts had involved the whole family, such as a christening vase. Others belonged to the 
children's own domain like a first pencil box. Many interviewees mentioned that they kept their original items as their own mementos, for example the first stuffed animal given them. This shows that even very young children make space for their own remembrance.

The strong personal relationship with the past of children is evidenced also by a strong diary culture, which was clearly evident in children participating in the study. Over half of the children said that they had kept a diary, which is remarkable given that some of the participating children were just learning to write (see table 2). Keeping a diary was typical common among girls. Boys, on the other hand, seemed to shun it.

Table 2. Diary-keeping of 7-10-year-old girls and boys (n 174)

\begin{tabular}{|l|l|l|l|l|l|}
\hline Grade & $\begin{array}{l}\text { Kept a diary: } \\
\text { Girls (\% of } \\
\text { girls) }\end{array}$ & $\begin{array}{l}\text { Kept a diary: } \\
\text { Boys }(\% \text { of } \\
\text { boys })\end{array}$ & $\begin{array}{l}\text { Not kept a } \\
\text { diary: Girls (\% } \\
\text { of girls) }\end{array}$ & $\begin{array}{l}\text { Not kept a } \\
\text { diary: Boys (\% } \\
\text { of boys) }\end{array}$ & Total \\
\hline $1-2$ & $59(80 \%)$ & $19(28 \%)$ & $15(20 \%)$ & $49(78 \%)$ & 142 \\
\hline $3-4$ & $10(67 \%)$ & $6(35 \%)$ & $5(33 \%)$ & $11(65 \%)$ & 32 \\
\hline Total & $69(78 \%)$ & $25(29 \%)$ & $20(22 \%)$ & $60(71 \%)$ & 174 \\
\hline
\end{tabular}

Likewise, with regard to children's collecting culture, collecting itself seemed more significant than the value of collected objects. The collected objects were often found in nature (rocks, chestnuts) or were obtainable with children's pocket money (glossy pictures, stickers). Eighty per cent of the children participating in the interview (140 children) said that collecting was their hobby. Collecting was a hobby both for girls and boys. Collecting is closely linked with the processing of the past, since it was important for the children to remember where and when they acquired their collected objects. Some of the children were also continuing a collecting hobby started by their parents when they were children.

\section{Women as mediators of the past}

One objective of this study was to determine the key factors in transmitting information about the past to children. The interviewees were asked to name a relative who had been telling them the most about the past and relatives they had met within the past 12 months. They were also asked to mention relatives who were present when they had visited museums and historical sites. It was made evident that the interviewees had very strong connections with their relatives, and that the intergenerational narrative tradition was active. A striking result was that women appeared to play a more significant role as mediators of the past than men. Mothers, grandmothers and aunts looked at photos, talked about their own past and visited museums with the children more than fathers, grandfathers and uncles.

Some researchers argue that young people wish to hear 'real' history from their grandparents. Parents' experiences are important for them but still secondary compared with information from two generations past (e.g. Onken 2004: 240, 245). Family history has been found to be more relevant to young people than national 
history. Maria Grever and Kees Ribbens (2007) noted this when studying 14-16-yearold adolescents in England and the Netherlands. One-third of young Dutch regarded their own family history as the most important, whereas one-ninth considered Dutch history to be the more significant. Similar results were found in England. Grever and Ribbens formed a hypothesis on the decreasing predominance of national history in popular culture (Ribbens 2007: 68).

Sirkka Ahonen has examined the same issue in Finland. According to her study (1998), 16-18-year-old Finns were interested in the history of their own family. However, she found that previous generations practiced self-censorship. Members of these generations considered it pointless to share with their descendants the negative aspects of the past. Thus generational interaction turned out to be quite weak in Ahonen's study. Due to this weak intergenerational remembrance, she argued, young people anchored their historical identities to the wars between Finland and Soviet Union largely through the strong influence of Finnish war movies (Ahonen 1998: 79, 130, 170-172).

Ahonen concluded her interviews in the late 1990s. Comparing the present study with hers, some findings have changed significantly. Nowadays family seems to play a very important role in the formation of children's historical identities. Almost all interviewees (162) had discussed the past with family members within the last 12 months. Most often they had discussions with both parents (56 interviewees). Almost as many interviewees (53) said that their mother told them about things related to the past. It is surprising that grandmothers, too, outperformed fathers as narrators of the past. More than one-fifth of the interviewees (38) said that their grandmothers were the key figures telling them about the past, whereas fathers were mentioned less frequently (27). Women's strong interest in history also appears in Roy Rosenzweig and David Thelen's study. Women were more active than men in seven out of ten history-related activities. Women outnumbered men for example in taking photos, writing in journals, attending family reunions, investigating their family's past, and participating in groups devoted to studying, preserving or presenting the past. (Rosenzweig and Thelen 1998: 28-29.)

In 2010 the author conducted seven interviews with the parents of the interviewees to find out how they explain women's fundamental role in the formation of their children's perceptions of the past. Both mothers (5) and fathers (2) considered that transmitting the family traditions belongs primarily to women. The explanation of women's more active role as mediators of the past is related to the ways and situations in which women talk about the past to their children. Women mention history while engaged in everyday activities. While baking, for example, women talk about how their own mothers used to bake, and while shopping they mention which kinds of groceries were available when they were children. Men however, transmit 'the real history' where dates and historical facts are crucial. Particularly young children are therefore not as receptive to their fathers' and grandfathers' stories.

The present study suggests that the intergenerational remembrance tradition is not withering. Changes in Finnish society can be one explanation for this. The interviewees' parents and grandparents mostly live in the same district, in this case the greater Helsinki area. Thus children have close relations with their families. The 
previous younger generation, i.e. that which participated in Ahonen's study, were still feeling the effects of the urbanisation of Finnish society. Their grandparents remained in the countryside when their parents moved to cities in the 1960s and 1970s.

Therefore these children could not have as strong relations with their grandparents as the members of the following generation. Strong remembrance practices can also be explained by parents' and grandparents' willingness to discuss the past with their descendants because they did not themselves have as traumatic experiences as the members of generation who lived during the war.

\section{Conclusion}

In Rosenzweig and Thelen's study Americans reported having not thought about the past until their adulthood. When these interviewees were young, they were thinking about the present and the future. (Rosenzweig and Thelen 1998: 64-66.) Are young people therefore too immature to process information about the past? The present study suggests not, as it found that even the youngest of children are interested in the past related to their own family. They are eager to know how everyday life differed from when their parents and grandparents were children.

Almost all interviewees in the present study had strong connections to the past through their families' practices of remembrance. Women proved to be the primary mediators of the past. Mothers and grandmothers look at photos with children, take children to museums and tell them about their families' past. The role of fathers and grandfathers as mediators of the past was found to be minor. Women's significant role can be explained by their strong presence in young children's everyday lives, and mothers talk about the past with their children in numerous domestic situations. Fathers, however, do not have as strong an everyday presence. Therefore their talk related to the past arises in less natural contexts.

The outcome of the interviews raises the question of the content of remembrance narration: Why do women as well transmit war stories to their descendants? Apparently, with the help of historical culture mothers and grandmothers have incorporated the wars between Finland and Soviet Union into their core conceptions of national history. Many Independence Day's celebrations and other national occasions are connected with the recollection of the Winter and Continuation Wars (1939-1944). Therefore women as well as men are trying to connect their family history to the Great Narrative of the wars. War history also has a tension that is usually lacking in everyday history. Therefore parents and grandparents have stressed the war theme in their own remembrance narratives. The majority of the interviewees revealed their knowledge of the wars between Finland and Russia. Nevertheless, to children today, contemporary Russia does not appear to be an enemy of Finland.

Through historical culture 7-10-year-old Finns have absorbed plenty of historical information for building their perceptions of the past. In particular they have listened to their family members' - especially mothers' and grandmothers' - recollections. The children have been prepared to adopt the Great Narrative of Finland. The future will show how this narrative will hold up against the new realities of globalisation and multiculturalism in contemporary Finnish society. 


\section{References}

Ahonen, S. (1998) Historiaton sukupolvi? Historian vastaanotto ja historiallisen identiteetin rakentuminen 1990-luvun nuorison keskuudessa [The No-History Generation? The Reception of History and the Construction of Historical Identity by Young People in the 1990s] (Helsinki: Suomen Historiallinen Seura).

Ahonen, S. (1999) Historiallinen identiteetti tutkimuskohteena [Studying historical identity]. Tieteessä tapahtuu 16 (2), 33-35.

Angvik, M. and Borries, B. von (eds) (1997) Youth and History. A Comparative European Survey on Historical Consciousness and Political Attitudes among Adolescents, A and B (Hamburg: Körber-Stiftung).

Ashton, P. and Hamilton, P. (2003) At home with the past: background and initial findings from the national survey. In P. Hamilton and P. Ashton (eds), Australians and the Past (University of Queensland), 5-30.

Berg, M. van den (2007) Yksi historia monimutkaistuvassa maailmassa. Historian olemus ja historian suuret kertomukset luokanopettajaopiskelijoiden historiatietoisuudessa [One History in a Multicomplex World. The quintessence of history and grand historical narratives in the historical consciousness of class teacher students] (Helsinki: Historiallis-yhteiskuntatiedollisen kasvatuksen tutkimus- ja kehittämiskeskus).

Cooper, H. (1994) Historical thinking and cognitive development in the teaching of history. In H. Bourdillon (ed.), Teaching history (London and New York: Routledge), 101-121.

Cooper, H. (2000) Primary school history in Europe. A staple diet or a hot potato? In J. Arthur and R. Phillips (eds), Issues in history teaching (London and New York: RoutledgeFalmer), 159-174.

Harle, V. and Moisio, S. (2000) Missä on Suomi? Kansallisen identiteettipolitiikan historia ja geopolitiikka [Where is Finland? The history and geopolitics of the national identity policy] (Tampere: Vastapaino).

Haue, H. (2008) Historical consciousness and culture of students in Denmark. In Historical consciousness - historical culture. Yearbook 2006/07 (Augsburg: International Society for the Didactics of History), 49-58.

Helve, H. (1987) Nuorten maailmankuva. Seurantatutkimus pääkaupunkiseudun erään lähiön nuorista [The World View of Young People. A longitudinal Study of Finnish Youth Living in a Suburb of Metropolitan Helsinki] (Helsinki: Kansalaiskasvatuksen keskus). 
Helve, H. (1993) The World View of Young People (Helsinki: Academia Scientiarum Fennica).

Helve, H. (2009) Nuorten vapaa-aika, luottamus ja sosiaalinen pääoma [Young People's Leisure Activities, Trust and Social Capital]. In M. Liikkanen (ed.), Suomalainen vapaa-aika [Finnish Leisure Time] (Helsinki: Gaudeamus), 250-269.

Historical Consciousness in Finland [www-document]. Available online at: http://blogs.helsinki.fi/historical-consciousness/, accessed September 15, 2010.

Jensen, B. E. (1998) Historiemedvetande - begreppsanalys, samhällsteori, didaktik. In Christer Karlegärd and Klas-Göran Karlsson (eds), Historiedidaktik (Lund:

Studentlitteratur), 49-81.

Kangas, S., Lundvall, A. and Sintonen, S. (2008) Lasten ja nuorten mediamaailma pähkinänkuoressa [The media world of children and youth in a nutshell] (Liikenne- ja viestintäministeriö, Lasten ja nuorten mediafoorumi) Available online at: http://www.lvm.fi/c/document_library/get_file?folderId=22170\&name=DLFE4803.pdf\&title=Lasten, accessed May 14, 2010.

Kids Top 100 Searches of 2009. Available online at: http://onlinefamilyinfo.norton.com/articles/kidsearches_2009.php, accessed May 14, 2010.

Knuuttila, K. (2009) Historiallinen muutos ja kansallinen kertomus Suomalaiset ja historia -esitutkimuksessa [Historical change and the national narrative in the feasibility study of Historical Consciousness in Finland]. An unpublished Master's Thesis (University of Helsinki, Faculty of Social Sciences).

Koivusalo-Kuusivaara, R. (2007) Lapset, media ja symbolinen vuorovaikutus. Suomalaisten, englantilaisten ja saksalaisten lasten mediasuhteen tarkastelua [Children, Media, and Symbolic Interactionism. Children's media relationship under inspection in Finland, England and Germany] (University of Helsinki, Faculty of Social Sciences, Department of Communication).

Laville, C. (2004) Historical Consciousness and Historical Education: What to Expect from the First for the Second. In P. Seixas (ed.), Theorizing Historical Consciousness (Toronto: University of Toronto Press), 165-182.

Létourneau, J. and Moisan, S. (2004) Young people's assimilation of a collective historical memory: A case study of Quebeckers of French-Canadian heritage. In P. Seixas (ed.), Theorizing historical consciousness (Toronto: University of Toronto Press), 109-128.

Létourneau, J. (2006). Remembering our past: An examination of the historical memory of young Québécois. In R. W. Sandwell (ed.), To the past. History education, public memory \& citizenship in Canada (Toronto: University of Toronto Press), 7087. 
Länsiluoto, T. (2008) Toiseuden tarinat, uhkan kuvat - Venäjä-kuva ja suomalaiskansallisen identiteetin rakentaminen 1970- ja 1990-luvun peruskoulun historian oppikirjoissa [Stories of the significant other, and the images of threat. The image of Russia and the building of Finnish national identity in history textbooks in the 1970s and 1990s]. An unpublished Master's Thesis (University of Helsinki, Faculty of Social Sciences), Available online at: https://oa.doria.fi/bitstream/handle/10024/39695/toiseude.pdf?sequence=2, accessed September 27, 2010.

Noppari, E., Uusitalo, N., Kupiainen, R. and Luostarinen, H. (2008) "Mä oon nyt online!" Lasten mediaympäristö muutoksessa ['I am online now!' The changing media environment of children] (University of Tampere, Department of Journalism).

Onken, E-C. (2004) The Legacy of parents and grandparents. How do young people in Central and Eastern Europe reflect on the communist past? In M. Robert (ed.), After the wall. History teaching in Europe since 1989 (Hamburg: Körber-Stiftung), 239-248.

Rantala, J. (2009) Peruskoulun alaluokkalaisten historiatietoisuus - lähtökohtia tutkimushankkeelle [The historical consciousness of primary school pupils]. Kasvatus 40 (1), 28-35.

Ribbens, K. (2007) A Narrative that Encompasses Our History: Historical Culture and History Teaching. In M. Grever and S. Stuurman (eds), Beyond the Canon. History for the Twenty-first Century (New York: Palgrave MacMillan), 63-76.

Rosenzweig, R. and Thelen, D. (1998) The presence of the past: popular uses of history in American life (New York: Columbia University Press).

Rubin, A. (1998) The images of the future of young Finnish people. (Turku School of Economics and Business Administration).

Rüsen, J. (2004) Historical Consciousness: Narrative, Structure, Moral Function and Ontogenic Development. In P. Seixas (ed.), Theorizing Historical Consciousness (Toronto: University of Toronto Press), 63-82.

Seixas, P. (2004) Introduction. In P. Seixas (ed.), Theorizing Historical Consciousness (Toronto: University of Toronto Press), 3-20.

Stuurman, S. and Grever, M. (2007) Introduction: Old Canons and New Histories. In M. Grever \& S. Stuurman (eds), Beyond the Canon. History for the Twenty-first Century (New York: Palgrave MacMillan), 1-16.

Suutarinen, S. (2000) Kansallisen identiteetin opettaminen ja uuden vuosituhannen haasteet [Teaching national identity, and the challenges of the new Millennium]. In S. Suutarinen (ed.), Nuoresta pätevä kansalainen. Yhteiskunnallinen opetus Suomen peruskouluissa [Training young people as competent citizens. Social education in comprehensive school in Finland] (Jyväskylän yliopiston koulutuksen tutkimuslaitos), 86-126. 
VanSledright, B. (2002) In Search of America's Past. Learning to read history in elementary school (New York and London: Teachers College Press). 